\title{
A Preliminary Investigation concerning the Glycogen Content of the Mucous Membrane of the Fallopian Tube
}

\author{
By Victor J. McAluster, M.B., B.Ch., B.A.O., F.R.C.S.I., \\ Assistant, Coombe Lying-in Hospital, Dublin.
}

ThIs paper comprises the results of a preliminary inquiry into the glycogen content of the Fallopian tube. It was undertaken at the suggestion of Dr. Ascheim, Director of the Laboratorium in the Frauenklinik of the Königlisches Charité Krankenhaus, Berlin, who has himself investigated very thoroughly the cyclic variations in the glycogen content of the endometrium. No one had as yet studied the problem in the Fallopian tube. In the case of the uterus the work of Hitschmann and Adler acted as a great stimulus to the investigation of the chemico-histological changes in the endometrium. These observers showed that undoubtedly the uterine mucous membrane underwent cyclic alterations in connection with the interval between successive menstrual periods. They showed that the whole period during which these changes were in progress, namely, the interval from one menstruation to the next, could be divided into four distinct stages, in each of which the mucous membrane presented a characteristic picture. They named these four periods the premenstrual, menstrual, post-menstrual and interval periods. The premenstrual stage, covering the interval from six to seven days before menstruation to the active onset of the flow, is characterized by the enlargement and distension of the glands, which are filled with secretion. The epithelial cells are also larger than at any other period; they look pale and distended, their nuclei staining indifferently. The protoplasm presents a somewhat granular appearance. In short, the epithelial cells show all the evidence of being actively engaged in secreting. These authors also found that the stroma cells in this stage, particularly those in the more superficial portions of the endometrium, tended to become enlarged, so as to resemble decidual cells.

In the menstrual period the glands are reduced in size, their lumen narrows and is no longer filled with secretions; the gland cells lose their swollen appearance and tend to become flattened, while here and there are seen extravasations of blood between, and sometimes inside, the glands.

Post-menstrually the glands are small and tend to be quite straight. The epithelial cells are of low type. All evidence of secretory activity is wanting, except in perhaps a few isolated glands. 
In the interval period, commencing a few days after menstruation, the glands show a tendency to become somewhat more tortuous and the epithelial cells somewhat less low, and so, gradually, become established once more the premenstrual type of gland, stroma and epithelial cell.

Following on this interesting work came the discovery by Lubarsch of the existence of glycogen in the uterine mucous membrane. This observation was confirmed by Gierke, who, however, at first failed to demonstrate its presence, but afterwards not only satisfied himself of its existence, but was so impressed by the marked variations in the amount present that he suggested a probable cyclic variation comparable to the cyclic structural changes described by Hitschmann and Adler. The matter was then further investigated by Ascheim and Wegelin, who were able to show that such a cyclic change actually did occur, and that, whereas during the menstrual, post-menstrual and interval stages but little glycogen, or none at all, was present, in the premenstrual stage the glycogen content of the epithelial and stroma cells was extremely large, so that, when appropriately stained, the protoplasm of the epithelial cells in the glands appeared usually of a uniform brilliant bright red. Ascheim found that both the surface epithelial cells and the gland cells contained glycogen. The glycogen during this stage could also be seen in the gland lumen in the form of granules of various sizes mixed up wih the mucus and other products of the secretory cells' activity. Lubarsch considered that in inflammatory conditions epithelial cells and also connective tissue and endothelial cells are capable of containing much glycogen. Both Ascheim and Wegelin found glycogen in the swollen decidual-like cells of the premenstrual period, but none in the post-menstrual or early part of the interval. The gland cells during these two later periods contain either no glycogen or very little. Such leucocytes as are met in the endometrium contain glycogen. In the second half of the interval period, although the majority of the glands contain no glycogen, still very often a few do. The glycogen granules are often very definitely arranged inside the cells, being sometimes collected basally, or towards the lumen, or again all to one or other side. In other cases the protoplasm is uniformly stuffed. The nuclei are always glycogen-free. In the lumen it occurs as distinct droplets of various sizes or as irregular granular masses of bright red colour in the Best method of staining. Apparently it can pass from the cell into the lumen of the gland without the former having to undergo total disintegration. The cervical glands are glycogen-free. During pregnancy Wegelin found much glycogen in the glands and decidual cells. In three cases where abortion had taken place thirty days to six weeks before the curettage the decidual cells of the serotina still contained glycogen. Wegelin found that, in general, when 
inflammatory changes were present in the endometrium, the glycogen content was increased, but never to the amount normally present during the premenstrual period.

Cl. Bernhard long ago showed that glycogen was normally present in the liver cells. It belongs to the polysaccharides of the formula $\mathrm{C}_{6} \mathrm{H}_{10} \mathrm{O}_{5}$, and is a white amorphous powder which disolves in water, yielding an opalescent solution, and is precipitated by alcohol. Probably there are different kinds of glycogen present in the liver, as only part can be extracted with hot water, the remainder requiring more elaborate treatment to bring about its recovery from the tissues. By means of ptyalin it is converted into dextrose. With iodine it stains brown, and this colour reaction is utilized in demonstrating its presence by the Weigert method and the more recent Lubarsch modification of the Weigert method. Both these methods are, however, superseded by. Best's kalium karmin method, which yields much more lasting preparations. With the exceptions of the granules in mast cells, mucus in goblet cells, and calcareous material, kalium karmin is a specific stain for glycogen. I found that paraffin sections yielded equally good results as celloidin sections. To avoid troublesome precipitation in employing Best's method, as much differentiating fluid as possible must be used after the specific glycogen stain, short of decolourizing any glycogen that may be present; rapid examinations under the microscope determine how far treatment with the solution can be pushed.

Glycogen is distributed throughout both the vegetable and animal kingdoms. In the embryo it is present in considerable quantity. It is always to be found in covering epithelium, striped muscle fibres and cartilage. It occurs less constantly in the epithelium of many glands, suprarenals, pancreas, heart, smooth muscle and serosaepithelium. In the liver glycogen appears for the first time in the later months of intra-uterine life. After birth glycogen is also normally present in the body, but in proportionally less quantity; thus its presence is constant in cartilage and many-layered epithelium. Other structures, such as nerves, breast-tissue, thyroid, pancreas, and pituitary, never contain it. In the blood it is normally present in the plasma and polymorphonuclear leucocytes. Both liver and muscle show considerable variations in the amount present, depending on the activity of metabolism and the amount of muscular exertion. The kidneys and lymph glands are practically glycogenfree. Cl. Bernhard found it in the placenta. Langhan studied its disposition in this structure more closely, and found that it was contained in the villi, Langhans' cells and the decidual cells. Driessen confirmed these findings, and showed that it was also present in the glands in the earlier months of pregnancy, but that in the second half of pregnancy it was absent. Broers found it in the musculature of the pregnant uterus. In diabetes the amount in the 
blood is increased, and Ehrlich found it in the epithelial cells of the kidney. In inflammatory conditions the leucocytes are full of it. Amongst tumours it occurs in such as consist of tissue which normally contains glycogen, as chondromata, squamous epitheliomata, but also in those composed of connective-tissue cells and endotheliomata. Particularly rich in glycogen are hypernephromata and chorioepitheliomata. In the corpus uteri foetalis Ascheim found glycogen always absent. As a rule post-climacteric uteri are glycogen-free, or contain mere traces. The glycogen present in the decidual cells seems to be of the "store-house" type, as is the case in the liver. Probably the decidua acts as a local depot for the supply of nutritive material, in part under the form of glycogen, to the rapidly growing embryo.

Glycogen in the Mucous Membrane of the Tube.

The material examined comprised the Fallopian tubes from 29 gynæcological and obstetrical cases of different kinds operated on in the Franenklinik of the Koniglisches Charité Krankenhaus, Berlin, and those from a still-born full-time fotus. The operations were for uterine rupture, fibromyoma, carcinoma ovarii, pregnancy complicated by fibroids, salpingitis, metritis, carcinoma of cervix, tubal pregnancy, pregnancy in a case of phthisis, and ovarian cyst. The only post mortem material was that from the full-time foetus. The tissue was put almost immediately after removal by operation into absolute alcohol. It is important that as little time as possible elapse between removal and fixation in alcohol, as glycogen begins to disintegrate very soon after the death of the cells containing it. Paraffin embedding was employed and the sections cut of between $8 \mu$ and $10 \mu$ thickness. With a view to comparing the amounts of glycogen in different preparations it was found more useful to preserve a uniform thickness for the sections; thus in $5 \mu$ sections the cells appear to contain much less glycogen than in $12 \mu$ sections, even though the tissue be identical. When possible the endometrium was examined along with the corresponding tube. The different portions of the tube, when available, were separately investigated.

With each batch of slides prepared a " control," which was known to contain glycogen, was also stained. For the demonstration of glycogen Best's karmin method was chiefly relied upon. Lubarsch's iodine method was only used as a control where such was deemed necessary. Many of the preparations were also examined for mucus.

Incidentally, as far as it went, the examination of the endometrium, when such was available, confirmed the observations of Ascheim regarding the cyclic changes in its glycogen content.

$I$ found glycogen present in the epithelial cells of the mucous membrane of seven of the tubes examined. The first tube in which I found it was from a case of metritis. The cylindrical epithelial 


\section{McAllister : Glycogen in Tubal Mucosa}

cells lining the lumen were quite full of glycogen, which could also be seen as droplets of various sizes often clumped together so as to form an amorphous granular mass in the lumen. The muscle fibres, particularly close to the lumen, also contained a large amount of glycogen. There was no evidence of salpingitis. The epithelial cells everywhere were swollen, but in places some were observed enlarged to about four times their normal size, their protoplasm full of glycogen granules.

The next case where the tube mucous membrane was found to contain glycogen in large amount was one of extensive uterine fibromyoma complicating a five months' intrauterine pregnancy. The mucous membrane of the isthmial portion of the left tube showed a particularly rich glycogen content, also that of the ampulla on the same side. The glycogen appeared in the form of minute granules in the protoplasm of the epithelial cells, and also on their free border lying in the tube lumen. The muscle fibres of the tube wall, and to a less extent those belonging to the rather large arterioles present, also showed glycogen granules, splashes and semilunes. The polymorphonuclear leucocytes which were rather numerous in the tube wall, were also rich in glycogen. The isthmial portion of the right tube showed but little glycogen, and the ampullary portion none except a little in the muscle. The corpus luteum was present in the right ovary, and its cells were found in places to contain distinct traces of glycogen. This was the only instance in which I found glycogen in corpus luteum cells.

In a case of carcinoma of the portio vaginalis uteri the endometrium was glycogen-free, the patient having ceased to menstruate a week previous to operation. The tube mucous membrane and the muscle fibres close to the lumen of the tube, as well as the lumen itself, showed its presence in considerable quantity. The cancer cells contained glycogen here and there in the form of minute grains. Both ampullary and isthmial portions of the tube showed the glycogen.

In a case of uterine rupture at full time the mucous membrane and the muscular tissue close to the lumen of the isthmial portion of the tubes contained glycogen in considerable amount. The corpus luteum was glycogen-free.

In a case of hysterectomy for fibromyoma the glands of the endometrium were packed with glycogen, whilst the tubes were glycogen-free.

In a case of early tubal gestation, in which the plicæ in the tube contained numbers of decidua cells only a few of the latter showed mere traces of glycogen. Neither muscle fibres nor mucous membrane showed glycogen.

In a case of uterine rupture at full term decidua cells found in one of the tubes (isthmus) contained mere traces of glycogen; the 
muscle fibres showed a good deal, while the epithelial cells of the mucous membrane were nearly glycogen-free.

The isthmial tubes belonging to a two months' pregnant uterus showed no trace of glycogen.

In an early case of salpingitis operated on a week after cessation of previous menstruation there was no glycogen in the tube except in the polymorphonuclear lencocytes.

In a case of carcinoma colli the endometrium contained some glands which showed considerable glycogen content, as also did the superficial epithelial cells. The majority of the glands were glycogen-free, and so was the tube.

In a case of hysterectomy for fibromyoma ten days after the cessation of the preceding menstruation the entire tube was glycogenfree.

In a case of early isthmial tubal pregnancy with rupture, the ampulla epithelium contained much glycogen. The actual site of the pregnancy was not examined. The muscle fibres were also rich in glycogen.

In a case of salpingitis with extensive infiltration of the plicæ and presence of many plasma cells, operated on four weeks after previous menstruation, there was no glycogen present except in the polymorphonuclear leucocytes.

In a case of tubal abortion and hæmatocele operated on two months after last menstruation the tube was glycogen-free.

In a case of hysterectomy for myoma a week after menstruation, the tube mucous membrane was glycogen-free, but the muscle fibres contained some.

In a case of hysterectomy for myoma about three weeks after cessation of previous menstruation, the endometrium was typically premenstrual and the glands very rich in glycogen. The tube mucous membrane contained no glycogen, the muscle fibres a little.

In a case of salpingitis with intense infiltration, glycogen was absent, except in the leucocytes, where it was plentiful.

In the tube of the foetus at full-time I found no glycogen in any of the divisions. In the endometrium only once did I see a gland the cells of which contained a small amount of glycogen. The fœetal ovary was glycogen-free.

In carrying out this investigation I had two chief aims in view, the first being to discover whether the mucous membrane of the tube ever contained glycogen, and the second to discover whether, in the case of a positive finding regarding the presence of glycogen, the glycogen content was subject to a cyclic variation in relation to menstruation, as is the case with the endometrium. The first question I have been able to answer definitely in the affirmative, as in seven of the tubes examined glycogen was present in considerable amount in the cells of the mucous membrane. My investigation further shows 


\section{McAllister : Glycogen in 'Tubal Mucosa}

that pregnancy is not essential to the presence of the glycogen. The second question requires further investigation which $I$ hope to be able to carry out at a later date, but my results allow me to state that undoubtedly the glycogen content of the mucous membrane of the tube undergoes considerable variations, and that, at a time when the endometrium presents all the signs of secretory activity and the epithelial cells of its glands are loaded with glycogen, the mucous membrane of the tube can be glycogen-free, and, vice versâ, when the endometrium is free from the glycogen, the tube mucous membrane may contain it in considerable amount. The extremely small glycogen content of the tubal decidual cells in my preparations is interesting as contrasting with the usually large content of intrauterine decidual cells. Inflammation seemed to exercise no effect in increasing the amount of glycogen present in the tubal epithelial cells. Only once did I find glycogen in the cells of the corpus luteum and even then the amount was very small.

In connection with this investigation I saw evidence that glycogen is probably not the only substance in the mucous membrane of the female genital tract which undergoes cyclic changes in relation to menstruation. In this preliminary communication $I$ have confined myself, however, to the facts concerning glycogen and its variations.

\section{LITERATURE.}

Ascheim. "Uber der Glykogengehalt der Uterus-schleimhaut.."

Barfurth. Anatom., Hefte Bd. 9 .

Brau1t. "La prognose des tumeurs basee sur la recherche du Glykogene," Paris, I899.

Büttner. Arch. für Gynäk., Bd. 92, I9Io.

Gebhart. Path. Anatom, der Weib. Sexualorgane.

Gierke. "Physiologische und pathologische Glykogenablagerung." Lubarsch-Ostertags Ergebnisse der allg. Pathol., Bd. II, 1907.

Hitschmann und Adler. "Der Bau der Uterusschleimhaut der Geschlectsreifen Weibes mit besonderer Berucksichtigung der Menstruation." Monatschr. für Geburtsh und Gynäk., Bd. 27.

Hitschmann und Adler. "Die Dysmenorrhcea membran." Ibid.

Langhans. "Uber Glykogen in pathologischen Neubildungen $\mathfrak{u}$. den menshlichen Eihaüten. Virchow's Arch., Bd. 120, I90.

Lubarsch. " Uber die Bedeutung des pathologisches Glykogen ablagerung. Virchow's Archiv., Bd. 183, 1906.

Mandl. Monatschr. für Geburtsh und Gynäk., Bd. 34, I9II.

Wegelin. "Der Glykogengehalt der mensclichen Uterus-schleimhaut." Zeitschr. für allg. Pathologie, I9II.

Wyder. Arch. für Gynäk., Bd. 13. Zeitschr. Jür Gynäk., Bd. 9. 